Impact of abiotic stress on photosynthetic efficiency and leaf temperature in sunflower

Utjecaj stresnih uvjeta uzgoja suncokreta na indeks fotosintetske učinkovitosti i temperaturu lista

Markulj Kulundžić, A., Kovačević, J., Viljevac Vuletić, M., Josipović, A., Liović, I., Mijić, A., Lepeduš, H., Matoša Kočar, M.

Poljoprivreda/Agriculture

ISSN: $1848-8080$ (Online)

ISSN: 1330-7142 (Print)

http://dx.doi.org/10.18047/poljo.22.2.3

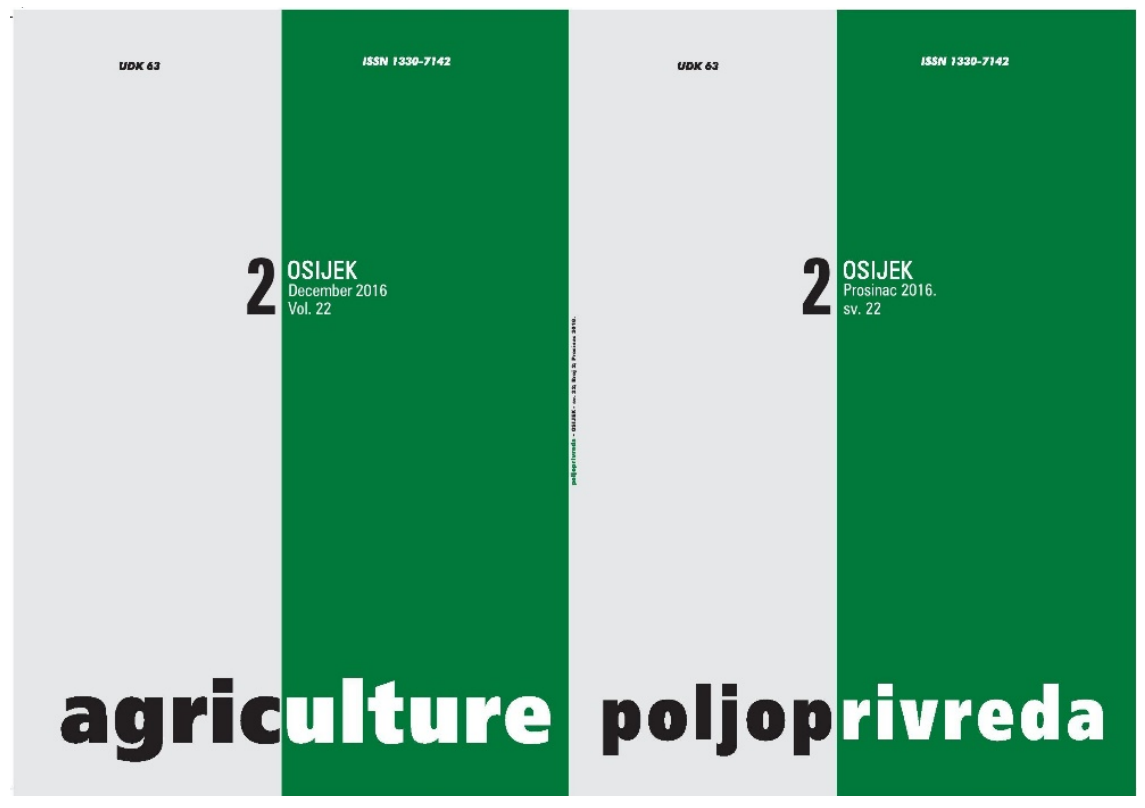

Poljoprivredni fakultet u Osijeku, Poljoprivredni institut Osijek

Faculty of Agriculture in Osijek, Agricultural Institute Osijek 


\title{
IMPACT OF ABIOTIC STRESS ON PHOTOSYNTHETIC EFFICIENCY AND LEAF TEMPERATURE IN SUNFLOWER
}

\author{
Markulj Kulundžić, A. ${ }^{(1)}$, Kovačević, J.(1), Viljevac Vuletić, M. ${ }^{(1)}$, Josipović, A. ${ }^{(1)}$, Liović, I. ${ }^{(1)}$, Mijić, A. ${ }^{(1)}$, \\ Lepeduš, H. ${ }^{(2)}$, Matoša Kočar, M. ${ }^{(1)}$
}

Original scientific paper

Izvorni znanstveni članak

\begin{abstract}
SUMMARY
The aim of this research was to investigate the variability of photosynthetic performance index $\left(\mathrm{PI}_{A B S}\right)$ and leaf temperature values measured in V6 development phase on 13 sunflower hybrids, grown in stressful conditions. The pot trial was made up of two treatments, one (T1) with 60\% Field Water Capacity (FWC), and the other one (T2) with $80 \%$ FWC. Significant differences between T1 and T2 treatments were established for both of these parameters which prove their dependence on the water content in the soil, while the influence of hybrid was evident only in the case of $\mathrm{PI}_{A B S}$. Although in T1, as opposed to T2, all sunflower hybrids reacted by increasing leaf temperature, reaction to stress conditions measured with $\mathrm{PI}_{A B S}$ parameter was not uniform. Some of the hybrids reacted by decreasing $P_{A B S}$ values, while others reacted by increasing their $\boldsymbol{P I}_{A B S}$ values. Therefore, it can be concluded that changes in parameters were independent of each other, which was confirmed by correlation analysis. Investigated parameters are suitable for determining the existence of undesirable environmental conditions that cause stress in plants and can be used in breeding of sunflower to withstand abiotic stress conditions, i.e. in selection of stress tolerant hybrids.
\end{abstract}

Key-words: Helianthus annuus, soil water content, hybrid, correlation

\section{INTRODUCTION}

Environment is a set of complex biotic and abiotic factors that affect the plants. Influence of environmental factors depends on their intensity and importance for plant development. For some of the individual plant species, environmental factors are essential for life, and can even have very harmful effects of their development, while for other species they are less important. Adverse environmental factors such as drought (Šimunić et al., 2007; Viljevac et al., 2012), extreme temperatures (Černý et al., 2011), heavy metals (Tuba et al., 2010; Mathur et al., 2016) and soil salinity (Yokoi et al., 2002; Dąbrowski et al., 2016) are stressful for many agronomic traits. Among abiotic stress factors, the most significant is drought, i.e. lack of water and high air temperatures that are closely connected, and can create significant problems at 1/3 of the world's areas (Škorić, 2012).

Sunflower is one of the plant species that can tolerate lack of water in combination with high temperatures of soil and air very well. It has the ability to partially reduce the adverse effects of drought, but it will in result react by reducing grain yield and oil content, as agronomic traits that are very depended on the weather conditions during the growing season (Krizmanić et al. 2012).

The importance of water for plant productivity and its irreplaceability is based on the diverse functions they have in their metabolism (Pevalek-Kozlina 2003). Tolerance of plants to drought can be expressed through their ability to maintain physiological processes such as photosynthesis under low water potential (Poormohammad Kiani et al. 2008). Lack of water in the soil for growing crops, primarily stunts growth and development by causing the closure of stomata which consequently reduces transpiration, so plant

(1) Antonela Markulj Kulundžić, M. Eng. Agr. (antonela.markulj@poljinos. hr), Ph.D. Josip Kovačević, Ph.D. Marija Viljevac Vuletić, Ana Josipović, M. Eng. Agr., Ph.D. Ivica Liović, Ph.D. Anto Mijić, Maja Matoša Kočar, M. Eng. Agr. - Agricultural Institute Osijek, Južno predgrađe 17, 31000 Osijek, Croatia, (2) Ph.D. Hrvoje Lepeduš - Josip Juraj Strossmayer University of Osijek, Faculty of Humanities and Social Sciences, 31000 Osijek, Croatia 
loses its turgor, it also changes plant's photosynthetic efficiency and metabolism which may lead to its death (Jaleel et al., 2009). In the past decade a very common method for determining photosynthetic efficiency was measuring chlorophyll a fluorescence, which is a noninvasive method that allows a quick assessment of the plant's physiological state (Goltsev et al., 2016). Under unfavourable environmental conditions this method estimates plant vitality (Dąbrowski et al., 2016) by detecting changes in the components of photosystem II, electron transport chain and photochemical reactions (Borawska-Jarmułowicz et al., 2014). One of the most commonly applied photosynthetic parameters used to assess the condition of the plants is photosynthetic performance index $\left(\mathrm{Pl}_{\mathrm{ABS}}\right)$ (Kalaji et al., 2016) which gives an insight into the overall flow of energy through the photosystem II (Force et al., 2003).

The same as for water in the soil, different plant species and varieties have specific requirements to temperature conditions which differ in different stages of plant growth and development. Factors that affect leaf temperature are solar irradiation, evaporation, heating and heat transport to or from air (van Berkum, 2008). During sunny summer days and in shortage of water, leaf temperature can be 4 to $5^{\circ} \mathrm{C}$ higher than air temperature. It depends on the ambient temperature, but it is never completely identical (Pevalek-Kozlina, 2003). Leaf temperature affects the rate of growth and development of plants, it determines the balance between energy which leaf receives and energy which it returns. The sudden rise in leaf's temperature is likely response to the shortage of water and consequence of the closing of the stomata which prevents evaporation and therefore cooling of leaf (van Berkum, 2008). According to research of Pallas et al. (1967) cotton leaf temperature (Gossypium hirsutum L.) grown in soil that has been well watered was slightly higher than environmental temperature, while for the plants which were grown under the soil water deficit leaf temperature was $3.4^{\circ} \mathrm{C}$ higher than environmental temperature.

The aim of this research was to determine changes in photosynthetic performance index and leaf temperature in sunflower hybrids during stress caused by drought. We assume that tested hybrids will respond differently to drought stress due to their genetic divergence and that tested properties can become useful selection method in further breeding procedures.

\section{MATERIAL AND METHODS}

The investigation of photosynthetic performance index $\left(\mathrm{Pl}_{\mathrm{ABS}}\right)$ and leaf temperature (LT) in stressful growth conditions included 13 sunflower hybrids, some of which were created within the sunflower breeding program at the Agricultural Institute Osijek (Osijek, Republic of Croatia) and some were introductions. Hybrids were developed from different source populations and they vary in plant height, head diameter and the genetic potential for yield. Hybrids were grown in the greenhouse in 12 litre volume vegetation pots. Eight sunflower seeds (four holes, two seeds in each) per pot were sown on May 25, 2012 at three cm depth and 10 $\mathrm{cm}$ apart. The soil used was silty clay loam (FAO 2006). Plants were tinned to two plants per pot in V4 phase, according to Schneiter and Miller (1981). The experiment was set up according to the randomized complete block design, in two treatments with three replications (78 plants per treatment).

Plants were studied in two irrigation treatments where the first treatment (T1) was maintained at $60 \%$ of Filed Water Capacity (FWC) while the second treatment (T2) was at $80 \%$ of FWC. According to data of the soil analyses, soil water capacity was $28 \%$ of weight (40.04\% of volume), which represents $100 \%$ FWC. Soil water content in vegetation pots was maintained at $80 \%$ FWC, according to Josipović et al. (2013), in both treatments up until V6 stage (developed six true leaves - Schneiter and Miller 1981), after which the water content in the treatment $\mathrm{T1}$, before measuring $\mathrm{Pl}_{\mathrm{ABS}}$ and $\mathrm{LT}$, was lowered to $60 \%$ FWC which represents wilting point according to the soil data analysis. Average air temperature in the greenhouse was $38.5^{\circ} \mathrm{C}$ and average relative air humidity $23 \%$, so one day was enough to reduce soil's water content to $60 \%$ FWC. FWC in the soil was determined by using the gravimetric method, whereas soil water content was determined by weighting pots during experiment and calculated as the difference between water content at $100 \%$ FWC and soil water consumption in each pot of both treatments.

Chlorophyll a fluorescence and LT were measured 25 days after sowing (June 19), in V6 vegetation stage. $\mathrm{PI}_{\mathrm{ABS}}$ was measured on three, while LT was measured on one developed peak leaf for each hybrid. $\mathrm{PI}_{\mathrm{ABS}}$ was determined by measuring the increase in chlorophyll a fluorescence after the application of saturating light pulse by using the Plant Efficiency Analyser (PEA - Hansatech, England). Data obtained by measuring fluorescence were used for calculating parameter that describes efficiency of photosynthetic system, i.e. $\mathrm{PI}_{\mathrm{ABS}}$ with OJIP test (Strasser et al., 2004). Half-hour before the measurements, leaves were adapted to darkness with special plastic clips. LT was measured using device Dual focus infrared thermometer $(B+B$ Thermo-Technik $\mathrm{GmbH}$, Germany). The ability of a material to transmit heat radiation is called emissivity and it should be adjusted to the type of material/tissue prior to measuring. Emissivity for sunflower tissue was determined according to Coll et al. (2001).

Analysis of variance (ANOVA) and correlation coefficients were calculated from the obtained data using SAS for Windows 9.3 software (SAS, 2014). The significant differences in main values were tested by Duncan test at level of $\mathrm{P}<0.05$.

\section{RESULTS AND DISCUSSION}

ANOVA showed statistically significant difference $(P<0.01)$ between treatments, hybrids and their intera- 
ctions for $\mathrm{PI}_{\mathrm{ABS}}$ parameter, but only between treatments for LT parameter (Table 1).

Table 1. ANOVA for treatments, sunflower hybrids and their interactions for photosynthetic performance index $\left(\mathrm{PI}_{\mathrm{ABS}}\right)$ and leaf temperature (LT)

Tablica 1. ANOVA tretmana, hibrida suncokreta i njihove interakcije za indeks fotosintetske učinkovitosti $\left(P I_{A B S}\right) i$ temperaturu lista (LT)

\begin{tabular}{|l|c|c|c|c|c|}
\hline \multirow{2}{*}{ Source } & \multirow{2}{*}{$\begin{array}{c}\text { Degree of } \\
\text { freedom }\end{array}$} & \multicolumn{2}{|c|}{ Mean square } & \multicolumn{2}{|c|}{ F value } \\
\cline { 3 - 6 } & & $\mathrm{PI}_{\mathrm{ABS}}$ & \multicolumn{1}{c|}{$\mathrm{LT}$} & $\mathrm{PI}_{\mathrm{ABS}}$ & $\mathrm{LT}$ \\
\hline Replication & 2 & 0.71 & 18.79 & 2.28 & 5.97 \\
\hline Treatment & 1 & 5.01 & 570.78 & $16.20^{* *}$ & $181.31^{* *}$ \\
\hline Hybrid & 12 & 3.25 & 4.07 & $10.53^{* *}$ & $1.29^{\text {ns }}$ \\
\hline $\begin{array}{l}\text { Treatment } x \\
\text { Hybrid }\end{array}$ & 12 & 3.29 & 1.56 & $10.65^{* *}$ & $0.50^{\text {ns }}$ \\
\hline Error & 50 & 0.31 & 3.15 & - & - \\
\hline Total & 77 & - & - & - & - \\
\hline
\end{tabular}

ns - not significant; ${ }^{* *}$ significant at $\mathrm{P}<0.01$

Under normal growing conditions the value variation range of parameter $\mathrm{PI}_{\mathrm{ABS}}$ was 0.63 to 3.04 , while the same values in stressful conditions varied from 0.76 to 4.76. According to Markulj et al. (2014) in R2 sunflower development stage (the size of the button is $0.5-2 \mathrm{~cm}$ ) under conditions of water deficit, $\mathrm{PI}_{\mathrm{ABS}}$ values ranged from 3.35 to 5.82 , while in conditions of sufficient water supply they varied from 4.07 to 6.07 . Although the average value of $\mathrm{PI}_{\mathrm{ABS}}$ in $\mathrm{T} 1$ was higher (1.99) compared to average value in T2 (1.48) (Figure 1), not all hybrids reacted equally. Some sunflower hybrids in $\mathrm{T} 1 \mathrm{had}$ higher values of $\mathrm{PI}_{\mathrm{ABS}}(\mathrm{H} 1, \mathrm{H} 4, \mathrm{H} 5, \mathrm{H} 7, \mathrm{H} 8, \mathrm{H}$, $\mathrm{H} 12)$, while the remaining hybrids reacted by decreasing their $\mathrm{PI}_{\mathrm{ABS}}$ values $(\mathrm{H} 2, \mathrm{H} 3, \mathrm{H} 6, \mathrm{H} 10, \mathrm{H} 11, \mathrm{H} 13)$ (Figure 1). The plants first reaction to drought stress in the early stages of its growth is an increase in photosynthetic performance index (Kovačević et al., 2013), which is considered defensive mechanisms of plant's photosynthetic apparatus on mild or moderate drought stress (Liu et al., 2010). A significant impact of treatments on $\mathrm{PI}_{\mathrm{ABS}}$ (Table 1) tells us that a change of this parameter can be used as an indicator of stress in different hybrids as confirmed by Cruz de Carvalho et al. (2010) and Lepeduš et al. (2012). Kalaji and Loboda (2007) in their investigation of cadmium and lead stress on barley, suggested parameters of photosynthetic efficiency as good indicators for controlling these pollutants at early stages of plant development. According to Want et al. (2016) photosynthetic efficiency under drought stress may be improved with adequate nitrogen supply. The difference in hybrids' reactions to abiotic stress, according to other researchers, allows us to select those which will have, in drought conditions, improved tolerance to arid conditions (Živčák et al., 2008; Gholamin et al., 2011). Similar results for $\mathrm{PI}_{A B S}$ in stress conditions were recorded by Viljevac et al. (2013) for cherries, Kovačević et al. (2013) for wheat and Ghobadi et al. (2013) for sunflower.
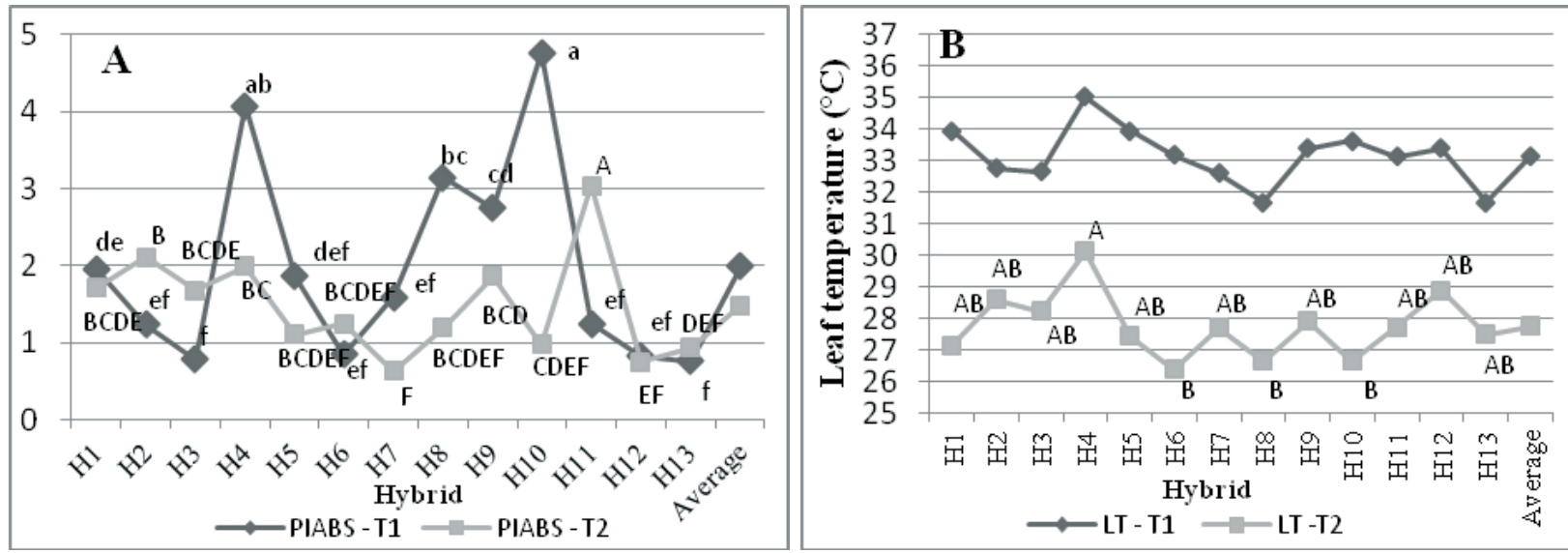

Figure 1. Values of photosynthetic performance index $\left(\mathrm{PI}_{\mathrm{ABS}}\right)(\mathrm{A})$ and leaf temperature (LT) (B) for hybrids in treatments (T1 - 60\% and T2 - 80\% of field water capacity). The letters indicate significant differences (small letters - 60\%; caps lock - 80\% FWC) between the mean values calculated with Duncan's test at $P<0.05$. Means with the same letter are not significantly different

Slika 1. Vrijednosti indeksa fotosintetske učinkovitosti $\left(P I_{A B S}\right)(A)$ i temperature lista (LT) (B) za hibride po tretmanima (T1 - 60\% i T2 - 80\% poljskoga vodnoga kapaciteta). Slova označavaju značajne razlike (mala slova - 60\%; velika slova - 80\% PVK) između srednjih vrijednosti izračunatih Duncan-ovim testom na $P<0,05$. Vrijednosti s istim slovom nisu značajno različite 
Although ANOVA showed no statistically significant differences between hybrids for LT (Table 1), Duncan's test found differences, but only for hybrids in normal growing conditions (Figure 1). Leaf temperature, which depends on the genetic diversity by Granier et al. (2002), development stage and the position of leaves during the measurement, ranged from 26.40 to $30.13^{\circ} \mathrm{C}$ in the normal conditions of water supply, while in dry conditions it ranged from 31.70 to $33.63^{\circ} \mathrm{C}$ (Figure 1). All hybrids reacted to stress by increasing their leaf temperature. Average mean value in $\mathrm{T} 1$ was $33.16^{\circ} \mathrm{C}$ and $27.77^{\circ} \mathrm{C}$ in $\mathrm{T} 2$ (Figure 1). High air temperatures reduce transpiration which leads to an increase in leaf temperature. Reducing the rate of transpiration in plants grown in drought conditions can also occur due to morphological changes such as increased thickness of the cell wall and cell wall lignification (Luvaha et al., 2008). Hybrid 4 had the highest value of $L T$ in both treatments, while H8 and $\mathrm{H} 13$ had the lowest LT values in stress conditions and $\mathrm{H} 6$ had the lowest values in normal growing conditions (Figure 1).

Unlike for parameter $\mathrm{PI}_{\mathrm{ABS}}$ where the influence of hybrids was clearly expressed, while their reaction was unequal, all hybrids reacted to stress uniformly by increasing their LT values, which is a clear indication of the existence of stress and can serve as an indicator of unfavourable conditions in the field.

Table 2. Correlation coefficients between index of photosynthetic performance $\left(\mathrm{PI}_{\mathrm{ABS}}\right)$ and leaf temperature (LT) in both treatments (T)

Tablica 2. Koeficijenti korelacije između indeksa fotosintetske učinkovitosti $\left(\mathrm{Pl}_{A B S}\right)$ i temperature lista za oba tretmana (T)

\begin{tabular}{|l|c|c|c|}
\hline Parameter & $\mathrm{PI}_{\mathrm{ABS}}-\mathrm{T} 1$ & $\mathrm{PI}_{\mathrm{ABS}}-\mathrm{T} 2$ & $\mathrm{LT}-\mathrm{T} 1$ \\
\hline $\mathrm{PI}_{\mathrm{ABS}}-\mathrm{T} 2$ & -0.008 & & \\
\hline $\mathrm{LT}-\mathrm{T} 1$ & 0.427 & 0.245 & \\
\hline $\mathrm{LT}-\mathrm{T} 2$ & 0.011 & 0.286 & 0.434 \\
\hline
\end{tabular}

$r=0.553 p<0.05 ; r=0.684 p<0.01$

Table 2 shows that no statistically significant correlation existed between tested parameters. Therefore, we can conclude that the changes in parameters were independent of each other. Similar results in sunflower butonisation were recorded by Markulj Kulundžić et al. (unpublished data).

\section{CONCLUSION}

Results of this research showed that stressful conditions during sunflower vegetation affected $\mathrm{PI}_{\mathrm{ABS}}$ and $\mathrm{LT}$ values. In conditions of soil water deficit $\mathrm{PI}_{\mathrm{ABS}}$ and $L T$ values were higher on average than values in conditions of sufficient soil water content. Although all hybrids responded by increasing LT in stressful conditions, their reaction measured by $\mathrm{PI}_{\mathrm{ABS}}$ value was not uniform. Some hybrids reacted to stressful conditions by an increase in $\mathrm{PI}_{A B S}$ values, while others by decreasing $\mathrm{PI}_{\mathrm{ABS}}$ values in comparison to conditions of normal soil water supply. This leads us to conclude that two measured parameters were not directly co-dependent, which was confirmed by correlation analysis. Measuring $\mathrm{PI}_{\mathrm{ABS}}$ and $\mathrm{LT}$ in early phases of development can be used in breeding programs for the development of sunflower hybrids with better adaptation to water and temperature stress. Both parameters are useful as indicators of stressful processes in plants, i.e. existence of undesirable environmental conditions which enable us to decide on any necessary agro-technical measures.

\section{ACKNOWLEDGEMENT}

This work is co-financed by the Ministry of Science, Education and Sports of the Republic of Croatia and is part of the research under the project "Stability of sunflower genotypes to important agronomic traits and oil quality" (073-0000000-3538).

\section{REFERENCES}

1. Borawska-Jarmułowicz, B., Mastalerczuk, G., Pietkiewicz, S., Kalaji, M.H. (2014): Low temperature and hardening effects on photosynthetic apparatus efficiency and survival of forage grass varieties. Plant Soil and Environmental, 60(4): 177-183.

2. Coll, C., Caselles, V., Rubio, E., Sospedra, F., Valor, E. (2001): Analysis of therminal infrared dana from the Digital Airborne Imaging Spectrometer. International Journal Remote Sensing, 22(18): 3703-3718.

3. Cruz de Carvalho, R., Cunha, A., Marques da Silva, J. (2010): Photosynthesis by six Portuguese maize cultivars during drought stress and recovery. Acta Physiologiae Plantarum, 33(2): 359-374. doi: http://dx.doi.org/10.1007/s11738-010-0555-1

4. Černý I., Veverková A., Kovár M., Pačuta V., Molnárová J. (2011): Influence of temperature and moisture conditions of locality on the yield formation of sunflower (Helianthus annuus L.). Acta Universitatis Agriculturae et Silviculturae Mendelianae Brunensis, LIX, 99-104. DOI: http://dx.doi.org/10.11118/actaun201159060099

5. Dąbrowski P., Baczewska A.H., Pawluśkiewicz B., Paunovc M., Alexantrov V., Goltsev V., Kalaji M.H. (2016): Prompt chlorophyll a fluorescence as a rapid tool for diagnostic changes in PSII structure inhibited by salt stress in Perennial ryegrass. Journal of Photochemistry \& Photobiology, B: Biology 157: 22-31. doi: http://dx.doi.org/10.1016/j.jphotobiol.2016.02.001

6. FAO 2006. Guidelines for soil description, Fourth edition. Food and Agriculture Organization of the United Nations, Rome. Available at: ftp://ftp.fao.org/agl/agll/docs/guidel_soil_descr.pdf.

7. Force, L., Critchley, C., van Rensen, J.S. (2003): New fluorescence parameters for monitoring photosynthesis in plants. Photosynthesis Research, 78: 17-23.

8. Ghobadi, M., Taherabadi, S., Ghobadi, M.E., Mohammadi, G.R., Jalali-Honarmand, S. (2013): Antioxidant capacity, photosynthetic characteristics and water relations of 
sunflower (Helianthus annuus L.) cultivars in response to drought stress. Industrial Crops and Products, 50: 29-38. doi: http://dx.doi.org/10.1016/j.indcrop.2013.07.009

9. Gholamin, R., Khayatnezhad, M. (2011): The effect of end season drought stress on the chlorophyll content, chlorophyll fluorescence parameters and yield in maize cultivars. Scientific Research and Essays, 6: 5351-5357. doi: http://dx.doi.org/10.5897/SRE11.914

10. Goltsev, V., Kalaji, M.H., Paunova, M., Babak, V. Horachekd, T., Moyskid, J., Kotsel, H., Allahverdieve, S.I. (2016): Variable chlorophyll fluorescence and its use for assessing physiological condition of plant photosynthetic apparatus. Russian Journal of Plant Physiology, 63(6):869-893. doi: http://dx.doi.org/10.1134/S1021443716050058

11. Granier, C., Massonnet, C., Turc, O., Muller, B., Chenu, K., Tardieu, F. (2002): Individual leaf development in Arabidopsis thaliana: a stable thermal-time-based programme. Annals of Botany, 89(5): 595-604. doi: http://dx.doi.org/10.1093/aob/mcf085

12. Jaleel, C.A., Manivannan, P., Wahidi, A., Ferooq, M., Jasim, Al-Juburi, H., Somasundaram, R., Panneerselvam, R. (2009): Drought stress in plants: A review on morphological characteristics and pigments composition. International Journal of Agriculture and Biology, 11: 100105.

13. Josipović, M., Kovačević, V., Rastija, D., Tadić, L., Šoštarić, J., Plavšić, H., Tadić, Z., Dugalić, K., Marković, M., Dadić, T., Šreng, Ž., Ljikar, Ž. (2013): Irrigation manual for project IRRI education participants. Poljoprivredni institut Osijek.

14. Kalaji, H.M., Jajoo, A., Oukarroum, A., Brestic, M., Zivcak, M., Samborska, A., Cetner, M.D., Łukasik, I., Goltsev, V., Ladle, R.J. (2016): Chlorophyll a fluorescence as a tool to monitor physiological status of plants under abiotic stress conditions. Acta Physiologiae Plantarum, 38:102. doi: http://dx.doi.org/10.1007/s11738-016-2113-y

15. Kalaji, H.M., Loboda, T. (2007): Photosystem II of barley seedlings under cadmium and lead stress. Plant soil and environment, 53(12): 511-516.

16. Kovačević, J., Kovačević, M., Cesar, V., Drezner, G., Lalić, A. Lepeduš, H., Zdunić, Z., Jurković, Z., Dvojković, K. Katanić, Z., Kovačević, V. (2013): Photosynthetic efficiency and quantitative reaction of bread winter wheat to mild short-term drought conditions. Turkish Journal of Agriculture and Forestry, 37: 385-393.

doi: http://dx.doi.org/0.3906/tar-1202-27

17. Krizmanić, M., Liović, I., Mijić, A., Krizmanić, G., Šimić, B., Duvnjak, T., Bilandžić, M., Marinković, R., Gadžo, D., Markulj, A. (2012): Effect of environment on quantitative traits of new OS sunflower hybrids. Sjemenarstvo, 29/34): 121-135.

18. Lepeduš, H., Brkić, I., Cesar, V., Jurković, V., Antunović, J., Brkić, J., Šimić, D. (2012): Chlorophyll fluorescence analysis of photosynthetic performance in seven maize inbred lines under water-limited conditions. Periodicum biologorum, 114(1): 73-76.

19. Liu, Z.H., Zhang, Z.B., Chu, L.Y., Shao, H.B. (2010): The corresponding relationship between roles of NADP-malic enzymes and abiotic stress in plants. Emirates Journal of Food and Agriculture 22: 239-249.

doi: http://dx.doi.org/10.9755/ejfa.v22i4.4872
20. Luvaha, E., Netondo, G.W., Ouma, G. (2008): Effect of water deficit on the physiological and morphological characteristics of mango (Mangifera Indica) rootstock seedlings. American Journal of Plant Physiology, 3(1): 1-15. doi: http://dx.doi.org/10.3923/ajpp.2008.1.15

21. Markulj, A., Viljevac Vuletić, M., Kovačević, J., Josipović, A., Liović, I., Mijić, A., Sudarić, A., Matoša Kočar, M. (2014): Water deficiency effects on photosynthetic performance in leaves of sunflower plants at developmental stage of butonisation. In: Proceedings of the 7th international scientific/professional conference "Agriculture in nature and environment protection". 28-30 Vukovar, p. 191-195.

22. Mathur, S., Kalaji, H.M., Jajoo, A. (2016): Investigation of deleterious effects of chromium phytotoxicity and photosynthesis in wheat plant. Photosynthetica, 54(2): 185-192. doi: http://dx.doi.org/0.1007/s11099-016-0198-6

23. Pallas, J.E., Michel, B.E., Harris, D.G. (1967): Photosynthesis, transpiration, leaf temperature, and stomatal activity of cotton plants under varying water potentials. Plant Physiology, 42(1): 76-88.

24. Pevalek-Kozlina, B. (2003): Photosyntesis. In: Plants Physiology, Profil.

25. Schneiter, A.A., Miller, J.F. (1981): Description of sunflower growth stages. Crop Science, 21: 901-903.

26. Šimunić, I., Husnjak, S., Tomić, F. (2007): Influence of drought on reduction of yields of agricultural crops. Agronomski glasnik, 5: 343-354.

27. Škorić, D. (2012): Sunflower breeding. In: Sunflower genetics and breeding. Kovačević, Z. (ed.), Serbian Academy of Sciences and Arts Branch in Novi Sad, 165-355.

28. Tuba, Z., Saxena, D.K., Srivastava, K., Singh, S., Czobel, S.M., Kalaji, H.M. (2010): Chlorophyll a fluorescence measurements for validating the tolerant bryophytes for heavy metal $(\mathrm{Pb})$ biomapping. Current Science, 98(11): 1505-1508.

29. Viljevac, M., Dugalić, K., Lepeduš, H., Mihaljević, I., Jurković, Z., Sudar, R., Cesar, V., Šimić D. (2012): Repeated measures analysis of changes in photosynthetic efficiency in sour cherry during water deficit. Poljoprivreda/Agriculture/, 18(1): 36-40.

30. Viljevac, M., Dugalić, K., Mihaljević, I., Šimić, D., Sudar, R., Jurković, Z., Lepeduš, H. (2013): Chlorophyll content, photosynthetic efficiency and genetic markers in two sour cherry (Prunus cerasus L.) genotypes under drought stress. Acta Botanica Croatica, 72(2): 221-235.

31. van Berkum E. (2008): Leaf temperature and the speed of growth. (http://blog.maripositas.org/horticulture/leaftemperature-and-the-speed-of-growth)

32. Wang, X, Wang, L, Shangguan, Z. (2016): Leaf gas exchange and fluorescence of two winter wheat varieties in response to drought stress and nitrogen supply. PLoS ONE, 11(11): e0165733. doi: http://dx.doi.org/10.1371/ journal.pone.0165733

33. Yokoi, S., Bressan, R.A., Hasegawa P.M. (2002): Salt Stress Tolerance of Plants. JIRCAS Working Report, 25-33.

34. Živčák, M., Brestič, M., Olšovská Slamka, P. (2008): Performance index as a sensitive indicator of water stress in Triticum aestivum L. Plant, Soil and Environment, 54(4): 133-139. 


\section{UTJECAJ STRESNIH UVJETA UZGOJA SUNCOKRETA NA INDEKS FOTOSINTETSKE UČINKOVITOSTI I TEMPERATURU LISTA}

\section{SAŽETAK}

Cilj ovog istraživanja bio je istražiti varijabilnost vrijednosti indeksa fotosintetske učinkovitosti (PI $\left.{ }_{A B S}\right)$ temperature lista, mjerenoj u V6 fazi razvoja u stresnim uvjetima uzgoja na 13 hibrida suncokreta. Pokus se sastojao od dva tretmana, jedan (T1) je predstavljao zasićenost tla vodom na $60 \%$ poljskoga vodnoga kapaciteta (PVK), a drugi (T2) na 80\% PVK. Utvrđene su statistički značajne razlike između T1 i T2 tretmana za oba navedena svojstva, što dokazuje njihovu ovisnost o sadržaju vode u tlu, dok je utjecaj hibrida utvrđen samo za PI $_{A B S .}$ lako su u T1, za razliku od T2, svi hibridi suncokreta reagirali s povećanjem temperature lista, reakcija na stresne uvjete izmjerene za svojstvo $P_{A B S}$ nisu bile jednake. Neki su od hibrida reagirali smanjenjem $P_{A B S}$ vrijednosti, dok su drugi reagirali povećanjem vrijednosti $P_{A B S}$. Iz dobivenih rezultata može se zaključiti da su promjene u svojstvima međusobno neovisne, što je potvrđeno i korelacijama. Istraživana su svojstva pogodna za utvrđivanje neželjenih okolišnih uvjeta koji uzrokuju stres na biljkama te se mogu koristiti u oplemenjivanju suncokreta za abiotske uvjete stresa, odnosno u odabiru hibrida tolerantnih na stres.

Ključne riječi: Helianthus annuus, sadržaj vode u tlu, hibrid, korelacija

(Received on 5 September 2016; accepted on 9 November 2016 - Primljeno 5. rujna 2016.; prihvaćeno 9. studenoga 2016.) 